\title{
Pengaruh Citra Aplikasi Kitabisacom terhadap Minat Donasi Generasi Milenial di Masa Pandemi Covid-19
}

\author{
Chelsea Erwan' ${ }^{1}$ Farid $^{2 *}$ \\ ${ }^{1}$ Fakultas Ilmu Komunikasi, Universitas Tarumanagara, Jakarta \\ Email: chelsea.915180279@stu.untar.ac.id \\ ${ }^{2}$ Fakultas Ilmu Komunikasi, Universitas Tarumanagara, Jakarta* \\ Email: farid@fikomuntar.ac.id
}

Masuk tanggal: 15-12-2021, revisi tanggal: 06-01-2022, diterima untuk diterbitkan tanggal: 16-01-2022

\begin{abstract}
The Kitabisacom application is a well-known platform to raise funds and donate which is available in smartphone or website in Indonesia. During the Covid-19 pandemic, Indonesians experienced economic difficulties. Some were infected with Covid-19 and couldn't pay for hospital fees. A lot of millennials use this application to make donations to those in need. To find out how the image of the Kitabisacom application affects millennial generation's interest in donations during Covid-19 pandemic and whether Kitabisacom application's image can increase millennial generation's interest in donations during Covid19 pandemic is the purpose. The theory used is the image theory from Sumardi (2021): (dynamic, cooperative, business, character, successful, and withdrawn) and Gilchrist's theory of donation interest (2019): (attitude, norms, and behavioral intention). This study uses quantitative approach with 100 samples of @ Kitabisacom Instagram followers through purposive sampling technique. From the simple linear regression test, every time there is an addition of a value or number for the influence of the Kitabisacom application image $(X)$, there will be an increase in donation interest $(Y)$ worth 0.443 (regression coefficient). The Ttest shows the influence of the Kitabisacom application's image on the millennial generation's interest in donations during the Covid-19 pandemic.
\end{abstract}

Keywords: Covid-19 pandemi, crowdfunding, donation interest, image, Kitabisacom application

\begin{abstract}
Abstrak
Aplikasi Kitabisacom merupakan platform untuk menggalang dana dan berdonasi yang tersedia dalam bentuk aplikasi smartphone maupun website yang terkenal di Indonesia. Selama pandemi Covid-19, sejumlah masyarakat Indonesia mengalami kesulitan ekonomi maupun terinfeksi Covid-19 dan tidak mampu membayar biaya rumah sakit. Generasi milenial menggunakan aplikasi Kitabisacom untuk menggalang dana ataupun melakukan donasi kepada yang membutuhkan. Penelitian ini ingin mengetahui apakah citra aplikasi Kitabisacom dapat meningkatkan minat donasi generasi milenial saat pandemi Covid-19. Teori yang digunakan yakni teori citra menurut Sumardi (2021) yaitu dynamic, cooperative, business, character, successful, dan withdrawn. Selain itu juga teori minat donasi oleh Gilchrist (2019) yaitu attitude, norms, dan behavioral intention. Metode penelitian yang digunakan yakni pendekatan kuantitatif serta metode survei dengan 100 sampel dari pengikut Instagram @Kitabisacom dengan non-probability sampling serta teknik purposive sampling. Dari uji regresi linear sederhana didapati bahwa setiap adanya penambahan angka atau nilai untuk pengaruh citra aplikasi Kitabisacom, maka akan terdapat kenaikan minat donasi senilai 0,443 (koefisien regresi). Uji T juga menunjukan adanya pengaruh citra aplikasi Kitabisacom terhadap minat donasi generasi milenial saat pandemi Covid-19.
\end{abstract}

Kata Kunci: aplikasi Kitabisacom, citra, crowdfunding, minat donasi, pandemi Covid-19 


\section{Pendahuluan}

Pandemi Covid-19 menyebabkan berbagai hambatan khususnya dalam sektor ekonomi dan kesehatan di Indonesia. Tidak sedikit pasien Covid-19 yang mengalami kesulitan membayar tagihan rumah sakit. Demi kesembuhan pasien, banyak dari keluarga maupun kerabat pasien berusaha mencari bantuan dari sumber lain yakni melalui donasi dari masyarakat.

Kebijakan Pemberlakuan Pembatasan Kegiatan Masyarakat (PPKM) membuat kegiatan donasi dilakukan melalui online dan tidak secara langsung. Dilansir dari TribunNews.com, riset yang dilakukan GoPay pada Agustus - Oktober 2020 menunjukkan bahwa pemberian donasi digital melonjak menjadi 72 persen selama pandemi Covid-19. Salah satu aplikasi donasi online di Indonesia adalah Kitabisacom. Kitabisacom merupakan platform untuk menggalang dana dan berdonasi yang tersedia dalam bentuk aplikasi smartphone maupun website. Aplikasi ini merupakan salah satu aplikasi donasi yang populer di berbagai kalangan, terutama kaum milenial.

Setiap perusahaan tak terkecuali Kitabisacom memiliki citra di mata masyarakat. Sementara itu, Katz dan Ardianto (2010) menuturkan bahwa citra merupakan cara konsumen ataupun seseorang memandang seseorang maupun perusahaan. Setiap perusahaan memiliki citra yang terbangun dari cara konsumen atau seseorang yang memandangnya (Savitri \& Erdiansyah, 2019). Kitabisacom pun membangun citra yang positif yakni sebagai aplikasi yang dapat membantu menyalurkan donasi dengan kredibel dan praktis. Berdiri sejak 2013, Kitabisacom merupakan salah satu aplikasi donasi online yang paling dikenal oleh publik. Tidak sedikit dari kaum milenial yang telah berdonasi di aplikasi Kitabisacom.

Generasi milenial merupakan kelompok yang menjadi subjek penelitian ini. Millennials yang dapat juga disebut dengan generasi Y merupakan orang yang lahir pada periode tahun 1980- 2000an, setelah generasi X. Millennials juga dianggap spesial sebab mereka sangat berbeda dengan generasi dahulu, terutama dalam segala hal yang bersangkutan dengan teknologi (Kusuma, 2020). Sejak pandemi Covid-19, banyak dari masyarakat termasuk generasi milenial yang memiliki kesadaran untuk berdonasi. Sehingga banyak penggalangan dana maupun donasi yang diadakan. Donasi tersebut ditujukan kepada tenaga medis, pasien Covid-19, maupun pasien lainnya yang sedang mengalami kesulitan ekonomi.

Schiffman dan Kanuk (2007) mengatakan bahwa minat adalah aktivitas psikis yang muncul yang disebabkan pikiran dan perasaan terhadap barang atau jasa yang disukai. (Bimo et al., 2015). Konsumen dapat memiliki minat donasi karena beberapa unsur seperti kredibilitasnya, keamanannya, maupun kepraktisannya. Citra yang tampak dari Kitabisacom telah tertanam di pikiran konsumen dan membentuk pandangannya terhadap aplikasi Kitabisacom. Kaum milenial tentunya memiliki pikiran dan pendapat tersendiri mengenai citra dari aplikasi Kitabisacom. Pikiran tersebut mungkin mempengaruhi minatnya untuk berdonasi melalui aplikasi Kitabisacom.

Penelitian ini memiliki tujuan untuk mengetahui apakah citra aplikasi Kitabisacom dapat meningkatkan minat donasi generasi milenial di masa pandemi Covid-19. Sementara itu, yang menjadi rumusan masalah dalam penelitian ini apakah citra aplikasi Kitabisacom dapat meningkatkan minat donasi generasi milenial di masa pandemi Covid-19? 
Citra dari suatu perusahaan/organisasi dapat terbagi menjadi beberapa dimensi. Menurut Fill (1999), dimensi citra terbagi menjadi enam bagian (Sumardi et al., 2021), sebagai berikut:

1) Dynamic

Perusahaan/organisasi selayaknya dinamis yakni menarik perhatian, aktif, menjadi pelopor,serta fokus pada tujuan. Dimensi dinamis terdiri dari beberapa unsur, yaitu: Attention-getting, Goal-oriented, Active, Pioneering.

2) Cooperative

Perusahaan/organisasi harus mampu bekerjasama dengan sikap bersahabat, digemari publik, membuat masyarakat senang, serta berhubungan baik dengan masyarakat. Cooperative terdiri dari beberapa hal, yakni: Eager to please, Well-liked, Eager to please, Friendly.

3) Business

Perusahaan/organisasi selayaknya mempunyai karakteristik bisnis yakni bijaksana, cerdas, persuasif, serta terorganisir dengan baik. Business terdiri dari beberapa unsur, yaitu: Shrewd, Persuasive, Wise, dan Well organized.

4) Character

Perusahaan/organisasi selayaknya mempunyai karakter yang juga baik yakni etika yang baik, reputasi baik serta terhormat. Character terdiri dari beberapa unsur: Reputable, Respectable, dan Ethical.

5) Successful

Perusahaan yang sukses adalah perusahaan yang memiliki kinerja keuangan baik serta mempunyai rasa percaya diri. Successful terdiri dari beberapa unsur: Financial performance dan Self-confidence.

6) Withdrawn

Perusahaan selayaknya mampu untuk menahan diri, menjaga rahasia, dan berhati -hati. Withdrawn terdiri dari beberapa unsur: Aloof, Secretive, dan Cautious.

Gilchrist menuturkan beberapa hal yang dapat mempengaruhi keinginan seseorang dalam melakukan kegiatan donasi (Triana K, 2020), sebagai berikut:

1) Attitude

\section{a. Attitude Towards Helping Others}

Hal ini menunjukkan kecenderungan perilaku seseorang yang ingin menyejahterakan orang lain dan tidak mementingkan dirinya sendiri (sikap altruisme), sehingga memiliki keinginan untuk membantu sesamanya yang sedang mengalami kesulitan ataupun terkena musibah.

b. Attitude Towards Charitable Organizations

Hal ini mengacu pada kecenderungan perilaku seseorang dalam memercayai penggalang donasi atau organisasi/perusahaan non-profit yang menginisiasi penggalangan dana sebelum akhirnya melakukan donasi ke organisasi/perusahaan tersebut.

2) Norms

\section{a. Descriptive Norms}

Hal ini mengacu pada keinginan seseorang untuk melakukan donasi karena dipengaruhi oleh banyaknya orang yang juga melakukan donasi.

b. Moral Norms

Hal ini mengacu pada keinginan seseorang untuk melakukan donasi yang dipengaruhi oleh moral yakni membantu orang-orang yang membutuhkan atau mengalami kesulitan finansial. 


\section{3) Behavioral Intention}

Hal ini mengacu pada kecenderungan niat seseorang untuk berperilaku dalam proses memutuskan sesuatu.

\section{Metode Penelitian}

Metode penelitian adalah sebuah cara ataupun jalan dalam rangka memecahkan segala permasalahan yang diajukan oleh peneliti (Bahry \& Zamzam, 2015). Pendekatan yang digunakan dalam penelitian ini adalah pendekatan kuantitatif. Menurut Usman (1996), pendekatan kuantitatif yakni penelitian yang mana terdapat penekanan terhadap analisis data-data numerik ataupun angka-angka yang didapatkan melalui metode statistik. Pendekatan ini juga dilaksanakan pada penelitian inferensial maupun dilakukan untuk pengujian hipotesis. Dengan demikian, dapat diperoleh hasil signifikansi hubungan antara variabel yang diteliti (Purwanti \& Amin, 2016).

Peneliti memilih pendekatan kuantitatif disebabkan oleh penelitian terdahulu yang juga meneliti soal citra menggunakan pendekatan kuantitatif. Citra pun merupakan sebuah gambaran dan kesan yang berbeda di mata publik yang beragam. Dengan demikian, data yang diperoleh akan beragam dengan meneliti sekelompok populasi yang luas dibanding wawancara beberapa orang. Adapun juga alasan lain yakni penulis ingin meneliti variabel (pengaruh citra aplikasi Kitabisacom terhadap minat donasi) terhadap populasi (generasi milenial). Dengan menggunakan pendekatan kuantitatif, data dari suatu variabel terhadap populasi dapat diperoleh dengan akurat.

Penelitian ini menggunakan metode survei sebagai metode penelitian. Dengan metode survei, peneliti dapat memperoleh data yang mewakili suatu populasi sesuai dengan kepentingan penelitian dan sudah ditentukan. Syarat yang dapat memenuhi dalam penelitian ini yakni responden yang merupakan followers akun Instagram @Kitabisacom serta merupakan generasi milenial. Hal ini berarti bahwa dalam penelitian ini pengambilan sampel dari populasi sebanyak 842.000 pengikut Instagram @ Kitabisacom per tanggal 20 September 2021 dilakukan dengan syarat tertentu yakni responden yang merupakan generasi milenial.

Dari hasil perhitungan ukuran sampel, didapatkan sampel dalam penelitian ini sejumlah 100 orang generasi milenial dari followers akun Instagram @ Kitabisacom. Karena responden yang ingin diteliti adalah generasi milenial maka teknik yang digunakan untuk menentukan sampel adalah non-probability sampling dengan teknik purposive sampling. Setelah melakukan perhitungan untuk menentukan ukuran sampel, diperoleh 100 sampel generasi milenial dari populasi sebanyak 842.000 pengikut per tanggal 20 September 2021.

\section{Hasil Temuan dan Diskusi}

Peneliti menyebarkan kuesioner kepada 100 responden dengan data yang diperoleh dari kuesioner dan diolah sebagai berikut: 
Chelsea Erwan, Farid: Pengaruh Citra Aplikasi Kitabisacom terhadap Minat Donasi Generasi Milenial di Masa Pandemi Covid-19

\section{Uji Normalitas}

Tabel 1. Hasil Uji Normalitas

One-Sample Kolmogorov-Smirnov Test

\begin{tabular}{|c|c|c|}
\hline \multicolumn{3}{|c|}{ One-Sample Kolmogorov-Smirnov Test } \\
\hline & & $\begin{array}{c}\text { Unstandardized } \\
\text { Residual }\end{array}$ \\
\hline \multicolumn{2}{|l|}{$\mathrm{N}$} & 100 \\
\hline \multirow[t]{2}{*}{ Normal Parameters ${ }^{a, b}$} & Mean &, 0000000 \\
\hline & Std. Deviation & 1,94900793 \\
\hline \multirow[t]{3}{*}{ Most Extreme Differences } & Absolute &, 105 \\
\hline & Positive & ,099 \\
\hline & Negative &,- 105 \\
\hline \multicolumn{2}{|l|}{ Test Statistic } & ,105 \\
\hline \multicolumn{2}{|l|}{ Exact Sig. (2-tailed) } & ,209 \\
\hline \multicolumn{2}{|l|}{ Point Probability } & ,000 \\
\hline \multicolumn{3}{|l|}{ a. Test distribution is Normal. } \\
\hline \multicolumn{3}{|l|}{ b. Calculated from data. } \\
\hline c. Lilliefors Significance Correction. & & \\
\hline
\end{tabular}

Sumber: Pengolahan Data oleh Peneliti

Setelah melakukan uji normalitas dengan menggunakan bantuan SPPS, peneliti memperoleh hasil sebagai berikut. Berdasarkan tabel 1 di atas, diketahui bahwa nilai Statistic Kolmogorov-Smirnov untuk seluruh variabel yakni 0,105 dan memiliki probabilitas signifikansi untuk seluruh variabel yaitu 0,209. Oleh sebab itu, dapat dinyatakan 0,209>0,05. Maka dari itu, dapat dinyatakan bahwa data dari seluruh variabel dalam penelitian ini normal.

\section{Uji Koefisien Korelasi}

Tabel 2. Hasil Uji Koefisien Korelasi

\begin{tabular}{|c|c|c|c|}
\hline \multicolumn{4}{|c|}{ Correlations } \\
\hline & & $\begin{array}{c}\text { Pengaruh Citra Aplikasi } \\
\text { Kitabisacom }\end{array}$ & $\begin{array}{l}\text { Minat } \\
\text { Donasi }\end{array}$ \\
\hline \multirow{3}{*}{$\begin{array}{c}\text { Pengaruh Citra Aplikasi } \\
\text { Kitabisacom }\end{array}$} & Pearson Correlation & 1 &, $725^{\text {** }}$ \\
\hline & Sig. (2-tailed) & & ,000 \\
\hline & $N$ & 100 & 100 \\
\hline \multirow[t]{3}{*}{ Minat Donasi } & Pearson Correlation &, $725^{* *}$ & 1 \\
\hline & Sig. (2-tailed) & 000 & \\
\hline & $N$ & 100 & 100 \\
\hline
\end{tabular}

Sumber: Pengolahan Data oleh Peneliti

Dari data yang didapatkan melalui uji regresi linear sederhana dan menggunakan aplikasi SPSS didapati hasil sebagai berikut. Berdasarkan pada tabel 2 dari atas, diperoleh bahwa nilai pearson correlation dari keseluruhan variabel pengaruh citra aplikasi Kitabisacom (X) dan minat donasi (Y) adalah 0,725. Dengan demikian dapat dinyatakan $0,725=$ hubungan kuat (korelasi). Dengan demikian, dapat dinyatakan bahwa variabel $\mathrm{x}$ dan y memiliki hubungan (korelasi) yang kuat.

Dari hasil dari tabel tersebut, didapati bahwa kedua variabel yakni variabel $\mathrm{x}$ dan y memiliki hubungan atau korelasi yang kuat. Hal ini berarti citra aplikasi 
Kitabisacom memiliki suatu pengaruh terhadap minat donasi generasi milenial di masa pandemi Covid-19.

\section{Uji Regresi Linear Sederhana dan Uji T}

Tabel 3. Hasil Uji Regresi Linear Sederhana dan Uji T

\begin{tabular}{|c|c|c|c|c|c|c|}
\hline \multicolumn{7}{|c|}{ Coefficients $^{\mathrm{a}}$} \\
\hline & \multirow[b]{2}{*}{ Model } & \multicolumn{2}{|c|}{$\begin{array}{c}\text { Unstandardized } \\
\text { Coefficients }\end{array}$} & \multirow{2}{*}{$\begin{array}{c}\text { Standardized } \\
\text { Coefficients }\end{array}$} & \multirow[b]{2}{*}{$\mathrm{t}$} & \multirow[b]{2}{*}{ Sig. } \\
\hline & & B & Std. Error & & & \\
\hline \multirow[t]{2}{*}{1} & (Constant) & 2,682 & 1,786 & & 1,502 & ,136 \\
\hline & $\begin{array}{c}\text { Pengaruh Citra Aplikasi } \\
\text { Kitabisacom }\end{array}$ & ,443 & ,043 &, 725 & 10,421 & ,000 \\
\hline
\end{tabular}

Sumber: Pengolahan Data oleh Peneliti

Berdasarkan data yang didapatkan dari uji regresi linear sederhana dengan menggunakan aplikasi SPSS didapatkan hasil berikut. Berdasarkan tabel 3 dari atas, persamaan regresi linier sederhana dari variabel pengaruh citra aplikasi Kitabisacom (X) terhadap minat donasi (Y) yang didapatkan dalam penelitian ini tertera dibawah ini:

$\mathrm{Y}=\mathrm{a}+\mathrm{bX}$

$Y=2,682+0,443 X$

Nilai 2,682 menunjukkan bahwa nilai minat donasi (Y) akan tetap konstan sebesar 2,682 jika nilai pengaruh citra aplikasi Kitabisacom (X) tidak mengalami perubahan turun ataupun naik. Nilai 0,443 adalah koefisien regresi yang menandakan bahwa setiap terdapat peningkatan suatu nilai atau angka untuk pengaruh citra aplikasi Kitabisacom (X), maka akan ada kenaikan minat donasi (Y) senilai 0,443. Maka dari itu, semakin bertambahnya nilai X, semakin bertambahnya nilai Y. Maka, semakin bertambah baiknya citra aplikasi Kitabisacom akan mempengaruhi minat donasi generasi milenial di masa pandemi Covid-19.

Selanjutnya, peneliti melakukan uji T dengan hasil berikut. Berdasarkan tabel 3 dari atas, didapatkan hasil uji t untuk variabel pengaruh citra aplikasi Kitabisacom (X) diperoleh $\mathrm{t}$ hitung yakni 10,421 dengan signifikan (Sig) sebesar 0,000. Berdasarkan derajat $(\mathrm{df})=\mathrm{N}-2=100-2=98$, dapat diperoleh $\mathrm{t}$ tabel sebesar 1,984. Hal tersebut mengartikan bahwa hasil Sig. yakni 0,000 $<0,05$ serta $t$ hitung $>t$ tabel $(10,421>1,984)$. Dengan begitu menunjukkan H1 diterima, yaitu adanya pengaruh citra aplikasi Kitabisacom (X) terhadap minat donasi (Y).

\section{Simpulan}

Berdasarkan data yang diperoleh melalui hasil analisis dan pembahasan mengenai pengaruh citra aplikasi Kitabisacom terhadap minat donasi generasi milenial di masa pandemi Covid-19, maka kesimpulan yang ditarik oleh peneliti diuraikan sebagai berikut: semakin baik citra aplikasi Kitabisacom, maka semakin tinggi juga pengaruhnya terhadap minat donasi generasi milenial di masa pandemi Covid-19. Hal tersebut dapat terjadi berdasarkan hasil uji regresi linear sederhana 
yang dilakukan pada penelitian ini. Nilai 0,443 merupakan koefisien regresi yang menunjukkan bahwa setiap ada penambahan suatu nilai atau angka untuk pengaruh citra aplikasi Kitabisacom (X), maka akan ada kenaikan minat donasi (Y) senilai 0,443 . Dengan demikian, semakin bertambahnya nilai $\mathrm{X}$ akan mempengaruhi nilai $\mathrm{Y}$. Maka dari itu, dapat disimpulkan bahwa citra aplikasi Kitabisacom memiliki pengaruh yang signifikan terhadap minat donasi generasi milenial di masa pandemi Covid-19.

H1 yang berbunyi "Terdapat pengaruh citra aplikasi Kitabisacom terhadap minat donasi generasi milenial di masa pandemi Covid-19" dalam penelitian ini diterima. Hal tersebut disebabkan oleh hasil uji $\mathrm{T}$ yang memiliki signifikansi yakni $0,000<0,05$. Hal tersebut menandakan bahwa minat donasi generasi milenial di masa pandemi Covid-19 mendapatkan pengaruh yang signifikan dari citra aplikasi Kitabisacom. Hal ini berarti citra aplikasi Kitabisacom memiliki pengaruh yang signifikan terhadap minat donasi generasi milenial di masa pandemic Covid-19.

Selain itu, hasil uji koefisien korelasi juga menunjukkan bahwa hubungan antara citra aplikasi Kitabisacom terhadap minat donasi generasi milenial di masa pandemi Covid-19 kuat. Hal tersebut dibuktikkan dari nilai pearson correlation dari keseluruhan variabel pengaruh citra aplikasi Kitabisacom (X) dan minat donasi (Y) adalah 0,725. Maka dapat dinyatakan $0,725=$ hubungan kuat (korelasi) menurut interval korelasi. Maka dari itu, dapat disimpulkan bahwa minat generasi milenial untuk berdonasi di aplikasi Kitabisacom sangat berhubungan dengan citra yang dimiliki dan dibangun oleh aplikasi Kitabisacom.

\section{Ucapan Terima Kasih}

Peneliti mengucapkan terima kasih kepada Fakultas Ilmu Komunikasi Universitas Tarumanagara, narasumber, serta semua pihak yang turut membantu peneliti sehingga penelitian ini dapat diselesaikan.

\section{Daftar Pustaka}

Bahri, Syamsul dan Zamzam, Fakhry. 2015. Model Penelitian Kuantitatif Berbasis SEM-Amos. Yogyakarta: Deepublish.

Bimo, Gagah., Putra, S., Kumadji, S., \& Hidayat, K. (2015). Pengaruh Citra Perusahaan Terhadap Minat Berkunjung dan Keputusan Berkunjung (Survei pada Pengunjung Taman Rekreasi PT.Selecta, Kota Batu, Jawa Timur). Jurnal Administrasi Bisnis (JAB)|Vol, 26(2).

Kusuma, Denny. (2020). Pusat Kegiatan Kaum Millenial. Jurnal Sains, Teknologi, $\begin{array}{llll}\text { Urban, Perancangan, Arsitektur (Stupa), } & \text { 1(2), } & 1117 .\end{array}$ https://doi.org/10.24912/STUPA.V1I2.4379

Lita Febriani. (2020, December 7). Riset GoPay: Donasi Digital Naik 72 Persen Selama Pandemi - $\quad$ Tribunnews.com. 1-3. https://www.tribunnews.com/techno/2020/12/07/riset-gopay-donasi-digitalnaik-72-persen-selama-pandemi

Purwanti, Nanda., \& Amin, A. (2016). Kepatuhan Ditinjau dari Kepribadian Ekstrovert-Introvert. Jurnal Psikologi Universitas Yudharta Pasuruan, 3, 8793. $\quad$ https://www.jurnal.yudharta.ac.id/v2/index.php/ILMUPSIKOLOGI/article/view/844

Savitri, S. Aprillia., \& Erdiansyah, R. (2019). Pengaruh Citra, Kredibilitas dan 
Kemampuan Komunikasi Beauty Vlogger Terhadap Keputusan Pembelian Produk Make-Up Maybelline (Studi Kasus Tasya Farasya). Prologia, 3(1), 267. https://doi.org/10.24912/PR.V3I1.6250

Sumardi, A. Putra., Priyowidodo, G., \& Tjahjo, J. D. W. (2021). Citra Pemerintah Kota Surabaya Pasca Surabaya Menjadi Zona Merah COVID-19 Di Mata Masyarakat Surabaya. Jurnal E-Komunikasi, 9(2). http://publication.petra.ac.id/index.php/ilmu-komunikasi/article/view/11522

Triana K, Kurniawan. (2020). Pengaruh Social Media Influencer Rachel Vennya terhadap Minat Donasi Followers Instagram @rachelvennya. https://kc.umn.ac.id/14143/ 